\title{
The Stuart Hall Conjuncture
}

\section{TONY BENNETT}

WESTERN SYDNEY UNIVERSITY

I recall distinctly when and where I first heard of Stuart Hall. It was in 1973 at a residential school I had organised at the University of Bristol on Marxism and Literature with Raymond Williams and E.P Thompson as its main-indeed, onlyspeakers. And it was Thompson who mentioned Stuart, saying that I ought to have asked him to speak in Thompson's place. I put this down to Thompson's characteristic modesty, for both he and Williams had commanded their audience's attention throughout a memorable weekend. But I logged the name and began to look up Stuart's work.

I didn't meet him, though, until after I had moved to the Open University (OU) some two to three years later. The context was the course Mass Communications and Society for which Stuart, who was still at Birmingham, was an external assessor. These were heady days at the OU. Very little pressure to do funded research, no key performance indicators to worry about, the OU a brand new and exciting venture,

ISSN 1837-8692

Cultural Studies Review 2016. ( 2016 Tony Bennett. This is an Open Access article distributed under the terms of the Creative Commons Attribution 4.0 Unported (CC BY 4.0) License

(https://creativecommons.org/licenses/by/4.0/), allowing third parties to copy and redistribute the material in any medium or format and to remix, transform, and build upon the material for any purpose, even commercially, provided the original work is properly cited and states its license. 
and lots of young academics eager to pass on what they had learned to a cohort of students who were mostly older than they were. Much of what we wrote was consequently too long, too abstract and too difficult. But it was also ambitious, challenging, full of disagreements-and so Stuart, deeply committed to intellectual dialogue as a pedagogic form, was entirely supportive.

I next met him toward the end of the 1970s when, about to embark on making the OU's Popular Culture course, I went to Birmingham to get his advice on how to approach the topic. This was at the time of Stuart's deep and enduring engagement with Gramsci's work, which we drew on to provide an overarching intellectual framework for the course. Shortly after, Stuart moved to the OU as the head of sociology, providing an unexpected opportunity to work closely with him; sadly, only for a year or two before I moved to Griffith University in 1983. I didn't see him again until 1990 at the University of Illinois Cultural Studies conference. I can still see him sitting on the stage, his head in his hands, unable to deliver his address until the protest against the conference organisation-a protest timed for his session so as to achieve maximum effect-had ended. But when he did finally get to speak it was electrifying.

Fast forward a few years and I next meet Stuart in 1998 in the lobby of a hotel in London's Russell Square. I am once again seeking his advice as his successor in the chair of sociology at the OU. Many people have said that this must have been a daunting challenge. But it wasn't. It might have been had I tried to imitate Stuart's particular style of leadership. But I was never tempted to do so, and I never had any concern that he would be anything but supportive. I was right.

Fast forward another few years, to 2004, to the last time I saw Stuart. The occasion was the launch of CRESC - the ESRC Centre for Research on Socio-Cultural Change. Stuart was one of four speakers invited to identify the social and cultural issues they would like the centre to engage with by way of registering the distance between Britain then and fifty years earlier when Williams's The Long Revolution was published. Stuart invoked the principles of conjunctural analysis to frame his presentation. I hadn't heard anyone speak about conjunctures for a long time the concept has never quite achieved critical traction in Australia) so I asked him if he could remind the audience what the principles of conjunctural analysis were. He did. 
And he has done so many times since. Indeed, if there is a leitmotif running through his work it is that of the conjuncture. It was a concept that acquired a distinctive liveliness in his handling of it, quite different from its more formalist Althusserian interpretation. 'The central concept of the Marxist science of politics (cf. Lenin's 'current moment'); it denotes the exact balance of forces, state of overdetermination of the contradictions at any given moment to which political tactics must be applied', so Ben Brewster's 1969 Althusser Glossary informs us. ${ }^{1}$ For Stuart, a conjuncture was both a moment of danger and one of opportunity; it was something to intervene in, a configuration whose components were to be rearranged through practice. It was a call to action-intellectual, social, cultural, political.

From the early 1970s crisis of law and order, through that of Thatcherism and the lost opportunity of New Labour-which he held in deep contempt-to the ongoing crises of the post-GFC neoliberal revolution, Stuart's intellectual engagements were defined in terms of the local manifestations of global conjunctures whose configurations were always regarded as pliable. This pliability had a distinctive form, one which reflected the Gramscian gloss that Stuart placed on the concept of the conjuncture through his theory of articulation, according to which the elements comprising any hegemonic formation could always be broken apart, and be given new meanings and political directions, through the conduct of politics as - for Stuart-mainly a set of ideological-discursive struggles.

Stuart's theory of articulation was, perhaps, his most influential contribution at a general theoretical level. It helped to shape, and was shaped by, the 'new democracy' theories of Ernesto Laclau and Chantal Mouffe, and it provided many a defining lexicon for cultural studies. It also informed what was perhaps his most decisive reshaping of cultural studies through the influence his account of the 'new ethnicities' has exercised on the ongoing de-essentialising of the categories of race and ethnicity that has been in process since the late 1970s.

His impact on the trajectories of British cultural studies in this regard was especially marked. When first bringing the perspectives of articulation theory to bear on the analysis of race and ethnicity, Stuart also aimed to shift the centrality that had hitherto been accorded the class-centric interpretation of cultures as ways of life within the Hoggart-Williams-Thompson trajectories of cultural studies. 
Williams took the point, at least as an abstract proposition, though without it ever really affecting his intellectual practice or political engagements.

There was, though, never any question of presenting race and class as competing alternatives; the point for Stuart was to attend to both in the context of the changing articulations of their relations to one another. But questions of race and ethnicity became increasingly important for him as his points of entry into such theoretical/political constellations. His project accorded questions of race and ethnicity a centrality that they had never previously enjoyed on the intellectual and political maps of the British left. Of course, there were precedents-in the 1930s, for example. But not in the context of a Britain whose composition was in the course of being lastingly altered by postwar migrations from the edges to the heart of empire; and not by someone who, as a representative of the Windrush generation, was a part of that movement.

This confluence of personal, political and intellectual trajectories was, in a sense, Stuart's very own conjuncture; his unique distillation of the conflicted histories that he lived through, struggled with and sought to reshape. And these were histories he did reshape by insisting there 'is no understanding Englishness without understanding its imperial and colonial connection'.2 This was an insistence that changed lives way, way beyond the reach of the academy.

For, in spite of his many academic accomplishments and honours, Stuart was a reluctant academic. He often interpreted his move to Birmingham after Perry Anderson's editorial coup at the New Left Review as a temporary retreat to the university where, he said, in spite of everything, real intellectual work could still be done. His commitment, after his retirement, to the development of the black arts movements in Britain, in championing the cause of Rivington Place, reflects a similar disposition. He always had a bigger picture in view than merely academic accomplishments.

Yet his persona, his life and his career are not adequately described by the notion of the public intellectual. This usually implies someone who is an intellectual first and who then goes public; a good candidate, these days, for high impact scores in research assessment schemes, but rarely for anything more enduring. The degree of public recognition that Stuart received was of a different order, coming closest to Weber's sense of charismatic authority as consisting in the role played by the 
exemplary qualities exhibited by an individual in setting new normative standards that serve as a template in guiding the conduct of others.

There aren't many, if any, higher accomplishments. At the same time, charisma has its limits and Stuart was aware of this, managing his adroitly, sometimes shrugging it off while at other times deploying it strategically. Conjunctural analysis has its weak spots, too. This is not the time or the occasion to dwell on these. However, as the time for memorialising recedes, 'the Stuart Hall conjuncture' is one that needs the kinds of critically robust assessments that he would have been the first to call for.

Tony Bennett is Research Professor at the Institute for Culture and Society at Western Sydney University.

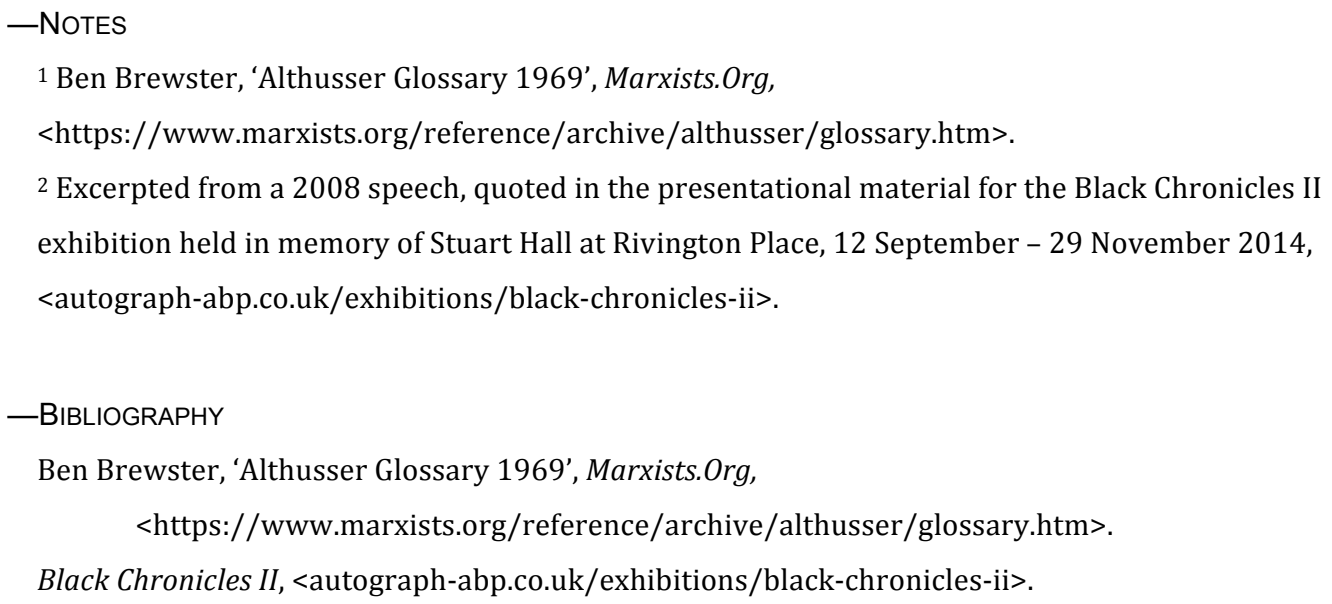

